\title{
PENGEMBANGAN INVESTASI WILAYAH PERBATASAN, INDUSTRI MARITIM DAN KAWASAN PERDAGANGAN BEBAS DALAM MENINGKATKAN KESEJAHTERAAN MASYARAKAT PESISIR DI PROVINSI KEPULAUAN RIAU
}

\author{
Tumpal Manik \\ Universitas Maritim Raja Ali Haji \\ tmanik@umrah.ac.id \\ Henry Eryanto \\ Universitas Negeri Jakarta \\ henry@unj.ac.id \\ Lia Suprihartini \\ Universitas Maritim Raja Ali Haji \\ Lia_supri@umrah.ac.id
}

\begin{abstract}
The purpose of this research to create the border region of investment development model, the maritime industry investment development model and Free Trade Zone development model effect on increase the welfareof coastal communities. The research location is in the of Riau Islands Province at Batam, Bintan and Karimun in 2016 with 200 research data. Analysis of the research through modeling path diagram, goodness of fit test (GOF) and the test results prove that the model evaluation through feasibility test models of assessment criteria Goodness of Fit (GOF) proved to be a model drawn up by researchers is the model has fit so that the model is said to fit the observed data development investment has met the criteria GOF through the test. Analysis of the research through modeling path diagram, goodness of fit test (GOF) and the test results prove that the model evaluation through feasibility studies Goodness of Fit (GOF) proven models arranged by researchers is the model has fit so that the model is said to fit the observed data to develop investment meets the criteria GOF through Chi-square test, probability of $>0.05, C M I N / D F \leq 2,00$, $R M S E A \leq 0,08, \quad G F I \geq 0,90, A G F I \geq 0,90, \quad T L I \geq 0,90, \quad N F I \geq 0,90, \quad C F I \geq 0.95$. The results of the research hypotheses prove that the investment development of border region, maritime industry and Free Trade Zone significant effect on increase the welfareof coastal communities in Riau Islands Province at Batam, Bintan and Karimun.
\end{abstract}


Keywords: Investment Development of border region Maritime Industry, the Frontier, the Free Trade Zone (Free Trade Zone), Coastal Community Welfare

\begin{abstract}
ABSTRAK
Tujuan dari penelitian ini adalah untuk menciptakan kawasan model pengembangan investasi, model investasi pengembangan industri maritim dan model pengembangan Kawasan Perdagangan Bebas di Provinsi Kepulauan Riau di Batam, Bintan dan Karimun pada tahun 2016 dengan 200 data penelitian. Analisis penelitian melalui diagram jalur pemodelan, goodness of fit test (GOF) dan hasil pengujian membuktikan bahwa model evaluasi melalui model uji kelayakan kriteria penilaian Goodness of Fit (GOF) terbukti menjadi model yang disusun oleh peneliti yaitu model Sudah sesuai sehingga model dikatakan sesuai dengan investasi pengembangan data yang teramati telah memenuhi kriteria GOF melalui pengujian. Analisis penelitian melalui diagram jalur pemodelan, goodness of fit test (GOF) dan hasil pengujian membuktikan bahwa model evaluasi melalui studi kelayakan Goodness of Fit (GOF) model terbukti dimodelkan kata Agar sesuai dengan data yang teramati untuk mengembangkan investasi memenuhi kriteria GOF Melalui uji Chi-kuadrat, probabilitas $>0,05, \mathrm{CMIN} / \mathrm{DF} \leq 2,00, \mathrm{RMSEA} \leq 0,08, \mathrm{GFI} \geq 0,90, \mathrm{AGFI} \geq 0,90$, TLI $\geq 0,90, \mathrm{NFI} \geq 0,90, \mathrm{CFI} \geq 0,95$. Hasil dari hipotesis penelitian membuktikan bahwa pengembangan investasi boder wilayah, industri maritim dan zona perdagangan bebas berpengaruh signifikan terhadap peningkatan kesejahteraan masyarakat pesisir di Provinsi Kepulauan Riau di Batam, Bintan dan Karimun.
\end{abstract}

Kata kunci: Pengembangan Investasi boder wilayah Industri Kelautan, Perbatasan,Kawasan Perdagangan Bebas (Free Trade Zone), Kesejahteraan Masyarakat Pesisir

\section{PENDAHULUAN}

Upaya mendorong pengembangan investasi bidang kelautan berbasis maritim, didasari pertimbangan bahwa Indonesia memiliki garis pantai terpanjang kedua di dunia, yang dapat dimanfaatkan untuk pengembangan investasi.Pengembangan pembangunan bidang kelautan ini, sesuai dengan visi Indonesia tentang poros maritim yang dikumandangkan Presiden Joko Widodo (Jokowi) saat menghadiri Konferensi Tingkat Tinggi (KTT) ke-
9 Asia Timur, di Nay Pyi Taw, Myanmar, pada akhir tahun 2014. Menurut Jokowo, Indonesia merupakan poros maritim dunia dikarenakan letak Indonesia yang berada di antara dua samudera yaitu Samudera Hindia dan Samudera Pasifik.

Lebih dari itu, adanya prioritas pembangunan Jokowi dalam bidang konektivitas maritim, melalui pembangunan tol laut, deep seaport, logistic, industri perkapalan, dan pariwisata maritim, sangat relevan dengan pengembangan 
investasi tersebut. Berdasarkan data juga diketahui, Indonesia memiliki tiga Alur Laut Kepulauan Indonesia (ALKI) dengan potensi nilai perdagangan 1,5 juta dollar AS per hari, setara dengan sekitar Rp 18 miliar perhari.

Kepulauan Riau (Kepri) sebagai provinsi yang memiliki wilayah lautan lebih luas daripada daratannya merupakan salah satu propinsi wilayah maritim yang ada di Indonesia. Kepri sebagai wilayah maritim sudah saatnya mengembangkan bidang industri maritim, seperti: mindustri transportasi perhubungan laut, pariwisata bahari, perikanan tangkap, pertambangan dan energi. Potensi alam laut ini merupakan andalan kekayaan yang dimilki Kepri dalam menjawab tantangan perkenomian berbasis maritim dengan potensi ini Provinsi Kepri dapat meningkatkan pertumbuhan perekonomian dan kesejahteraan masyarakat setempat khususnya masyarakat pesisir yang termarjinalkan di Indonesia.

Industri maritim dan kawasan perdagangan bebas di Provinsi Kepulauan Riau masih cerah dan menggairahkan mengingat dua pertiga wilayah Indonesia berupa laut dengan potensi dan prospek yang sangat luar biasa. Maka dari itu, butuh banyak lagi menarik investor baik lokal maupun international untuk mau berinvestasi pada industri maritim di Kepri sebagai wilayah perbatasan dan kawasan perdagangan bebas (free trade zone).

Penelitian ini berbeda dengan penelitian atau kajian sejenis yang dilakukan sebelumnya. Itu karena dalam penelitian terdahulu berfokus pada penyusunan model, strategi, dan kebijakan ditinjau dari wilayah perbatasan, industri maritim dan kawasan perdagangan bebas(free trade zone)saja. Hal tersebut mendorong tim peneliti untuk mengkaji serta menganalisis lebih lanjut tentang "Pengembangan Investasi Wilayah Perbatasan, Industri Maritim dan Kawasan Perdagangan Bebas dalam Meningkatkan Kesejahteraan Masyarakat Pesisir di Provinsi Kepu-lauan Riau".

Adapun tujuan penelitian ini adalah untuk menyusun ; 1) Model pengembangan investasi pada wilayah perbatasan, industri maritim dan kawasan perdagangan di Provinsi Kepri (Batam, Bintan dan Karimun), 2) Tersedianya identifikasi pengaruh model pengembangan investasi terhadap peningkatan kesejahteraan masyarakat pesisir di Provinsi Kepri (Batam, Bintan dan Karimun. 3) Tersusunnya strategi kebijakan yang perlu dan dapat diambil pemerintah daerah untuk meningkatkan pengembangan investasi berdasarkan hasil model yang dibangun pada Kota Batam, Kabupaten Bintan dan Kabupaten Karimun di Provinsi Kepulauan Riau.

\section{KAJIAN TEORITIK Pengembangan Investasi}

Menurut Reinhold (Reinhold, 2008),faktor pendorong pengembangan kawasan perbatasan adalah faktor prospek usaha meliputi daya tarik kawasan, image kawasan, prospek kawasan, kelancaran supply, kinerja, tingkat penjualan, 
pengelolaan

kemudahan

perijinan usaha meliputi kemudahan ijin usaha, kenyamanan usaha, kesediaan fasilitas pendukung penunjang kesiapan kawasan meliputi perumahan dan stabilitas keamanan, serta perdagangan jasa.

Kawasan perbatasan antar negara memiliki potensi strategis bagi berkembangnya kegiatan perdagangan internasional yang saling menguntungkan. Kawasan ini juga berpotensi besar menjadi pusat pertumbuhan wilayah, terutama dalam hal pengembangan industri, perdagangan dan pariwisata. Hal ini akan memberikan peluang bagi peningkatan kegiatan produksi yang selanjutnya akan menimbulkan berbagai efek pengganda (multiplier effects) (Effendi, 2012).

Tipologi pengembangan kawasan perbatasan dikembangkan Wu (2001), terdiri dari beberapa analisis tipelogi pengembangan kawasan perbatasan, antara lain: 1) tipe wilayah perbatasan, 2) hubungan ekonomi, 3) kerangka institusi atau pemerintah, 3) tipe perusahaan, 4) jaringan infrastruktur, 5) migrasi, 6) perbedaan upah buruh. Tipologi ini melalui pendekatan.

Program mengubah paradigma kawasan perbatasan dan wilayah pesisir menjadi kawasan investasi membutuhkan regulasi dan sistem yang tepat untuk memberikan kemudahan bagi investor untuk masuk ke kawasan tersebut, khusunya dalam menghadapi MEA, termasuk faktor-faktor pengembangan kawasan perbatasan yang dipengaruhi oleh 1) Penataan kelembagaan dan pelayanan penanaman modal, 2) Promosi dan meningkatkan daya tarik para penanaman modal atau investor, 3) Ketersediaan infrastruktur sebagai sarana dan prasarana.

\section{Pengembangan Investasi Wilayah Perbatasan}

Penataan kelembagaan dan pelayanan penanaman modal, mempengaruhi pengembangan investasi wilayah perbatasan sebagai dasar kajian dalam penelitian ini dan menjadi indikator yang sangat penting untuk dianalisis untuk menyusun model penelitian sejauh mana peranan dari kelembagaan dan pelayanan penanaman modal dalam mengembangan investasi wilayah perbatasan terdiri dari: 1) Peraturan pemerintah, 2) Ketersediaan kelembagaan pelayanan penanaman modal, 3) Penataan/pengelolaan kedudukan institusi penanaman modal, 4) Regulasi kemudahan dan kebijakan terhadap calon penanam modal, 5) Terlaksananya koordinasi kebijakan penanaman modal antara Instansi Penanaman Modal (IPMP)dengan SKPD terkait, 6) Terlaksananya koordinasi kebijakan penanaman modal antara pemerintah daerah dengan calon penanam modal, 7) Terlaksananya koordinasi kebijakan penanaman modal antara pemerintah provinsi dengan kabupaten/kota.

Melalui Promosi, pengembangan investasi untuk mencari calon investor dapat dilakukan melalui dua acara, yakni promosi dengan informasi kualitas investasi fortofolio atau jasa keuangan dan kedua adalah promosi sektor riil. Upaya mempercepat pertumbuhan ekonomi di Kepri, maka pengembangan 
sektor-sektor unggulan dapat dimulai dengan melakukan promosi yang efektif untuk mengundang investor, baik lokal maupun luar negeri dengan bauran promosi tradisional meliputi berbagai metode, mengkomunikasikan manfaat produk maupun jasa. Strategi yang dilakukan untuk mencapai hal tersebut adalah strategi aglomerasi, sinkronisasi, koordinasi, bantuan ahli, litbang pendidikan sertapromosi dengan pendekatan klaster hasil laut ((BKPM, 2011).

Menurut Sihaloho (Sihaloho, 2009), terdapat sejumlah faktor yang mempengaruhi kondusifitas iklim berinvestasi di Indonesia. Faktor-faktor tersebut menyangkut stabilitas politik dan sosial, stabilitas ekonomi, kondisi infrastruktur dasar (listrik, telekomunikasi dan prasarana jalan dan pelabuhan), berfungsinya sektor pembiayaan dan pasar tenaga kerja (termasuk isu-isu perburuhan), regulasi dan perpajakan, birokrasi (dalam waktu dan biaya yang diciptakan), masalah goodgovernance, konsistensi dan kepastian dalam kebijakan pemerintah yang langsung maupun tidak langsung mempengaruhi keuntungan neto atas biaya resiko jangka panjang darikegiatan investasi, dan hak milik mulai dari tanah sampai kontrak

\section{Pengembangan Investasi Industri Maritim}

Maritim merupakan wilayah yang memiliki laut lebih luas daripada daratan. Maritim juga menyangkut kelompok dari satuan kelautan, yaitu semua kegiatan yang berhubungan dengan pengelolaan dan pemanfaatan sumberdaya laut dan lingkungannya. Sektor kelautan mencakup kegiatan-kegiatan pemanfaatan, penambangan, angkutan dan jasa-jasalainnya yang berada di wilayah pesisir maupun di lautan, termasuk kegiatan industri kemaritiman (Kusumastanto, 2014).

Keterpaduan darat dan laut dalam pembangunan harus menjadi dasar spasial serta berorientasi pada wawasan nasional maupun global dengan mengutamakan kepentingan nasional. Perspektif pembangunan negara maritim juga didasari bahwa keberlanjutan pembangunan guna mencapai keberlanjutan bangsa Indonesia (Kusumastanto, 2014).

$\begin{array}{lcr}\text { Klasifikasi } & \text { potensi } & \text { sumber } \\ \text { daya maritim yang } & \text { dapat } \\ \text { dikembangkan } & \text { di } & \text { Provonsi }\end{array}$

Kepulauan Riau, antara lain: 1) Potensi perikanan tangkap laut, 2)Potensi Budidaya perikanan dan rumput laut, 3)Potensi Industri pengolahan hasil perikanan, 4) Potensi industri bioteknologi kelautan, 5) Potensi pertambangan seperti: minyak bumi, gas dan bauksit, 6)Potensi Energi terbarukan (agin, ombak, pasang, matahari). Potensi Wisata bahari antara lain pantai, pulau, laut, karang dan kapal, 7) Potensi transportasi perhubungan untuk jangkauan nasional dan internasional, 8) Potensi Bangunan kelautan seperti contoh dermaga, konstruksi dan rekayasa, 9)Potensi Benda berharga dan warisan budaya atau cultural heritage (Manik, 2014).

Perpres RI No. 39 Tahun 2014, mendambah daftar peluang dan potensi pengembangan 
investasi di bidang kemaritiman tentang daftar bidang usaha dengan persyaratan di bidang penanaman modal, bidang kelautan dan perikanan, antara lain: 1) perikanan, 2) usaha pengolahan hasil perikanan, 3) pembesaran dan pembenihan ikan laut, 4) usaha pengolahan hasil perikanan, 5) industri penggaraman/pengeringan ikan dan biota perairan lainnya, 6) usaha pengolahan hasil perikanan, 7) usaha pemasaran, distribusi, perdagangan besar, dan ekspor hasil perikanan.

Mandat UU No.10 tahun 2009 tentang kepariwisataan Bab IV pasal 7, 8, dan 9 pembangunan Kepariwisataan dilakukan berdasarkan Rencana Induk Pembangunan Kepariwisataan, yang terdiri atas rencana induk pembangunan kepariwisataan nasional, rencana induk pembangunan kepariwisataan provinsi, dan rencana induk pembangunan kepariwisataankabupaten/kota, hal ini sesuai dengan PP No. 50 tahun 2011, memiliki visi yaitu Terwujudnya Indonesia sebagai negara tujuan pariwisata berkelas dunia, berdaya saing, berkelanjutan, mampu mendorong pembangunan daerah dan kesejahteraan rakyat.Pembangunan kepariwisataan nasional meliputi destinasi pariwisata, pemasaran pariwisata, industri pariwisata dan kelembagaan kepariwisataan.

Produk dan daya tarik yang dapat dikembangkan pada pariwisata bahari di Batam, Bintan dan Karimun Provinsi Kepulauan Riau diantaranya adalah wisata bisnis, wisata pantai, wisata alam dan wisata olah raga (Manik, 2014).
Menurut Dahuri (Dahuri, 2010), sektor kegiatan pariwisata bahari mencakup kegiatan-kegiatan pariwisata bahari, pariwisata pantai, jasa penunjang pariwisata bahari seperti hotel, penginapan, restoran, rumah makan serta jasa penunjang pariwisara bahari.

Potensi industri maritim bidang industri perkapalan dan transportasi laut menjadi peluang bisnis yang prospektif di Kepri, sehingga akan lebih muda untuk mengundang para investor melakukan investasi juga berpotensi melakukan berbagai kerjasama dengan negara-negara tujuan ekspor sehingga dapat menambah devisa pemerintah. Revitalisasi industri galangan kapalengan investasi sebesar $\mathrm{Rp}$ 10,80 triliun seperti kapal kontainer, barang perintis, bulk carrier, tug \& barge, tanker dan kapal rakyat mencapai Rp 101,74 triliun. Serta pengadaan kapal patroli dari kelas IA sampai dengan kelas $V$ senilai Rp 6,04 trilium (Suroso, 2015).

Potensi industri maritim bidang transportasi perhubungan laut harus didukung industri perkapalan sebagai bagian eleman industri maritim, industri ini disebut industri padat karya dan padat modal yang memiliki daya saing tinggi. Pemerintah sebagai pemegang kewenangan sangat penting, makapihak pemerintah dan swasta diharapkan saling berkolaborasi dan bekerjasama memfasilitasi elemenelemen pembangunan industri transportasi perhubungan laut seperti contoh pelayanan sarana dermaga, pengelolaan pelabuhan dan industri perkapalan (Manik, 2014). 


\section{Pengembangan Investasi Kawas- an Perdagangan Bebas}

Posisi geografis Kepri sangat strategis menjadikan masa depan menjadi lebih penting, dilihat dari segi ekonomi global, karena ekonomi dunia/global telah bergeser dari Eropa, Amerika menuju ke Asia dan pusat-pusat perekonomian dunia yang ada di Jepang, Korea, Taiwan, Cina, India, Rusia, yang kesemuanya itu dicapai oleh pedagang-pedagang dari Eropa maupun Amerika lewat laut harus melewati selat malaka, dan begitu juga sebaliknya (Dimyati, 2009).

Pengembangan investasi kawasan perdagangan bebas di wilayah Kota Batam, Kabupaten Bintan dan Kabupaten Karimun di Provinsi Kepulauan Riau dikaji berdasarkan analisis faktor-faktor yang mempengaruhinya, antara lain: 1) Pengembangan industri manufaktur, 2) Pengembangan jasa, 3) Pengembangan sistem pendukung (support sistem) industri perdangan bebas.

Dasar hukum Penetapan Kawasan Perdagangan Bebas dan Pelabuhan Bebas (KPBPB) Batam, Bintan, Karimun (BBK) merupakan salah satu Kawasan Strategis Nasional (KSN) dan kandidat Kawasan Ekonomi Khusus (KEK) dalam bentuk KPBPB, dengan penandatanganan kesepakatan kerjasama ekonomi antara Pemerintah Indonesia dengan Pemerintah Singapura melalui PP No.46/2007 untuk Batam, PP No.47/2007 untuk Bintan dan PP No.48/2007 untuk Karimun sesuai pula Peraturan Presiden No. 9, 10, dan 11 Tahun 2008 tentang Dewan
Kawasan KPBPB Batam, Bintan, Karimun sebagai bentuk kelembagaannya.

Kawasan Perdagangan Bebas dan Pelabuhan Bebas (KPBPB) Batam, Bintan, Karimun (BBK) merupakan salah satu Kawasan Strategis Nasional (KSN) dan kandidat Kawasan Ekonomi Khusus (KEK) dalam bentuk KPBPB. Terkait dengan pengembangan kawasan ini, telah terdapat suatu proses penandatanganan kesepakatan kerjasama ekonomi antara Pemerintah Indonesia dengan Pemerintah Singapura. Kesepakatan kerjasama tersebut kemudian ditindaklanjuti dengan adanya penetapan lokasi pengembangan KPBPB melalui Peraturan Pemerintah No.46/2007 untuk KPBPB Batam, PP No.47/2007 untuk KPBPB Bintan dan PP No.48/2007 untuk KPBPB Karimun. Dalam rangka upaya operasionalisasi KPBPB Batam, Bintan, Karimun telah ditetapkan pula Peraturan Presiden No. 9, 10, dan 11 Tahun 2008 tentang Dewan Kawasan KPBPB Batam, Bintan, Karimun sebagai bentuk kelembagaannya. Tujuan penetapan kawasan perdagangan bebas adalah untuk meningkatkan pertubuhan ekonomi, kesejahteraan masyarakat dan memajukan wilayah tersebut.

Model pengembangan sistem pendukung (BBK PP No.48/2007), industri perdangan bebas dalam pengembangan investasi kawasan perdagangan bebasantara lain: 1) Insentif kegiatan riset dan pengembangan, 2) Kebijakan ketenagakerjaan, 3) Koordinasi dan penyederhanaan prosedur perijinan investasi melalui pelayanan satu 
pintu di Badan Pengusahaan masing-masing kawasan,

Koordinasi kemitraan pemerintahswasta dalam pembangunan, 5) Infrastruktur, 6) Kemitraan antara Badan Pengusahaan dan institusi pengelola, operator bertaraf dunia dalam pengelolaan kawasan, 7) Jaminan keamanan investasi dan kepastian usaha, 8) Tenaga kerja yang terampil dan world-class professionals, 9) Infrastruktur yang moderen dan memadai yang didukung oleh IT.

\section{Meningkatkan Kesejateraan Masyarakat Pesisir}

Keputusan Menteri Kelautan

Dan Perikanan No.18 Tahun 2004 tentang pedoman umum pelaksanaan Pemberdayaan Ekonomi Masyarakat Pesisir (PEMP), mencoba meletakan kembali dasar-dasar pengembangan kawasan pesisir dengan berbasis pemberdayaan masyarakat. Startegi penanggulangan pengentasan kemiskinan pada masyarakat pesisir yaitu dengan mendirikan unit kegiatan masyarakat misalnya mendidikan KUB (kelompok usaha bersama), khusus para nelayan adanya bantuan kepada masyarakat yang tidak mampu membeli peralatan ikan tangkap misalnya penyediaan kapal sederhana, penyediaan jaring atau alat tangkap, sedangkan hasil sumberdaya alam laut diolah menajdi poduk tahan lama dalam bentuk kemasan.

Pembinaan layanan dengan menyediakan ruang yang memadai bagi kegiatan masyarakat pesisir, yakni pemberian modal usaha dibidang industi kelautan, prasana dan prasarana untuk membantu unit kegiatan usaha masyarakat pesisir dan menyediakan fasilitas pengelolaan pemanfaatan sumber daya laut. Meningkatkan kesejahteraan masyarakat pesisir menggunakan berbagai model dan prinsip pengelolaan yang terpadu dilakukan berdasarkan analisis perspektif yang kolaboratif yang memadukan antara unsur masyarakat pengguna (kelompok nelayan, pengusaha perikanan) dan pemerintah yang dikenal dengan Co-management yang menghindari peran dominan yang berlebihan dari satu pihak dalam pengelolaan sumberdaya pesisir dan laut sehingga pembiasaan aspirasi pada satu pihak.

Model yang dibanguan dalam penelitian ini diidentifikasi melalui faktor-faktor yang mempengaruhi pengembangan investasi dikontruksi menjadi kuesioner yang diaplikasikan menjadi path diagram model menggunakan, SPSS dan SEM dengan Tools Amos V.22 untuk pengembangan investasi wilayah perbatasan, industri maritim dan kawasan perdagangan bebas dalam meningkakan kesejahteraan masyarakat pesisir. Sedangkan hipotesis yang dikaji adalah secara parsial diduga terdapat pengaruh pegembangan investasi wilayah perbatasan, industri maritim dan kawsan perdagangan bebas berpengaruh terhadap peningkatkan kesejahteraan masyarakat pesisir di Kepri (Batam, Bintan dan Karimun).

\section{METODOLOGI PENELITIAN}

Penelitian ini memilih lokasi di Kota Batam, Kabupaten Bintan, 
Kabupaten Karimun Provinsi Kepulauan Riau dengan objek pengamatan pada Industri Maritim, Wilayah Perbatasan, Kawasan Perdagangan Bebas dan Masyarakat Pesisir. Penentuan ketiga lokasi (Kota Batam, Kabupaten Bintan, Kabupaten Karimun) penelitian inikarena lokasi ini telah resmi mendapatkan fasilitas regulasi kawasan perdagangan bebas atau free trade zone (FTZ) yang berbatasan langsung dengan negara tetangga serta telah diupayakan sebagai pilot project pengembangan Kawasan Ekonomi Khusus (KEK).

Polulasi penelitian ini adalah masyarakat Kota Batam, Kabupaten Bintan, dan Kabupaten Karimun yang berhubungan dengan pengembangan investasi industri maritim, wilayah perbatasan, kawasan perdagangan bebas, masyarakat pesisir berada pada wilayah Batam, Bintan dan Karimun di Provinsi Kepulauan Riau. Pengambilan sampel menjadi data penelitian dengan menetapkan responden dari masyarakat yang berdomisili di Batam, Bintan dan Karimun yaitu masyarakat (penduduk) pesisir, para pegawai dan karyawan yang bekerja dibidang industri maritim antara lain industri kelautan dan perikanan, industri pariwisata, industri perkapalan.

Melengkapi model dan hasil penelitian ini, maka peneliti menyusun dua kategori variabel yaitu variabel laten dan variabel manifes yang dianggap membantu untuk memperoleh hasil dalam menyusun model, antara lain: a. Variabel Laten Eksogen, yang dikontruksikan dari hubungan variabel manifest terdiri dari tiga variabel, antara lain: Pengembangan Investasi Wilayah Perbatasan (Tata Kelolah Intansi Penanaman Modal $\left(\mathrm{X}_{1}\right)$,Promosi Meningkatkan Daya Tarik Investor $\left(\mathrm{X}_{2}\right)$, Ketersediaan Infrastruktur (Sarana dan Prasarana) $\left(X_{3}\right)$, Pengembangan Investasi Industri Maritim(Industri Maritim Bidang Perikanan $\left(\mathrm{X}_{4}\right)$, Industri Maritim Bidang Pariwisata Bahari $\left(X_{5}\right)$, Industri Maritim Bidang Perkapalan $\left(X_{6}\right)$, Pengembangan Investasi Kawasan Perdagangan Bebas(Pengembangan Industri Manufaktur $\left(X_{7}\right)$, Pengembangan Jasa $\left(X_{8}\right)$, Pengembangan Sistem Pendukung $\left(X_{9}\right)$

b. Variabel Laten Endogen, meningkatkan Kesejateraan Masyarakat Pesisir yang dikontruksikan hubungannya dengan variabel manifest dalam penelitian ini terdiri dari dua variabel, yaitu: Pembangunan Wilayah Pesisir $\left(Y_{1}\right)$ dan Kesejahteraan Masyarakat Pesisir $\left(\mathrm{Y}_{2}\right)$

\section{HASIL DAN PEMBAHASAN}

Hasil output statistik SPSS.V.22 dan Amos V.22 mengolah data sebanyak 200 data penelitian, menunjukkan nilai terendah adalah promosi, sebesar 5,00 dengan rata-rata 15,855 dengan standar deviasi sebesar 4,33450. Data tersebut berarti bahwa tingkat promosi untuk 
meningkatkan daya tarik investor masih rendah. Sedangkan nilai tertinggi adalah sistem pendukung sebesar 25,00 dengan rata-rata 16,6 dengan standar deviasisebesar 4,56 .

\section{Pengembangan Investasi Wilayah Perbatasan}

Evaluasi model dilakukan untuk menguji kelayakan model melalui kriteria penilaian Goodness of Fit (GOF). Hasil pengujian output path diagram pengembangan investasi wilayah perbatasan untuk goodness of fit dengan $\mathrm{df}=268$ antara lain: Chi-square $0,30, p$ (probabilitas) $0,078>0,05$, nilai probability adalah $0,078, \mathrm{CMIN} / \mathrm{DF}=$ $0,125 \leq 2,00, \operatorname{RMSEA}=0,031 \leq 0,08$ nilai uji goodness of fit menunjukkan bahwa nilai memenuhi syarat goodness of fit, hal ini berarti model yang dihipotesiskan telah cocok dengan data observasi. Kecocokan model juga didukung dengan nilai $\mathrm{GFI}=1,089 \geq 0,90$, AGFI $=\quad 0,998 \geq 0,90, \quad \mathrm{TLI}=$ $1,035 \geq 0,90, \mathrm{NFI}=1,088 \geq 0,90, \mathrm{CFI}=$ $1,078 \geq 0,90$ berada di atas nilai 0,9 dan nilai RMSEA berada antara interval 0,03 sampai 0,08 sehingga model pengembangan investasi wilayah perbatasan dikatakan cocok terhadap data observasi.

\section{Path Diagram Model Pengembangan Investasi Wilayah Perbatasan}

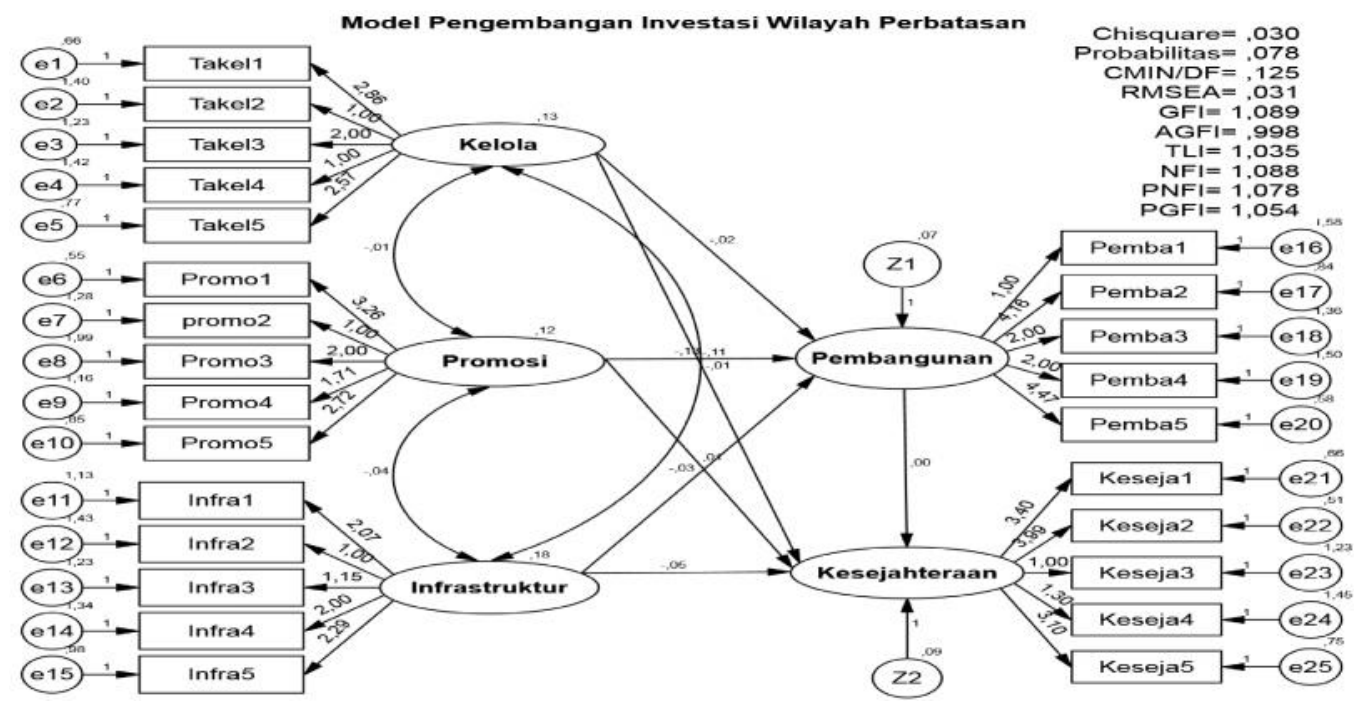

Gambar 1. Path Diagram Model

Pengembangan Investasi Wilayah Perbatasan

$\begin{array}{ll}\text { Dari hasil pengujian GOF } & \text { Hasil Estimasi Parameter dan } \\ \text { terbukti bahwa model hasil } & \text { Standard Error. Uji hipotesis } \\ \text { modifikasi terakhir fit dengan data } & \text { dilakukan dengan melihat nilai C.R. } \\ \text { yang ada. Oleh karena itu, } & (\text { critical ratio) nilai } \mathrm{CR}>1,96 \text { dan } \\ \text { pengujian hipotesis bisa dilakukan } & \text { nilai } \mathrm{P}<0,05 .\end{array}$
yang ditunjukkan pada Tabel 1. 
Tabel 1. Hasil Estimasi Parameter dan Standard Error

\begin{tabular}{|c|c|c|c|c|c|c|}
\hline \multicolumn{3}{|c|}{ Parameter } & Estimate & S.E. & C.R. & $P$ \\
\hline Pembangunar & $<--$ & Tata Kelola & 0,41 & 0,21 & 6,70 & $\star \star \star \star *$ \\
\hline Pembangunar & $<-$ & Promosi & 0,96 & 0,17 & 5,55 & $\star * \star$ \\
\hline Pembangunar & $<--$ & Infrastruktur & 0,30 & 0,10 & 2,88 & 0,00 \\
\hline Kesejahteraar & $<--$ & Pembangunan & 0,73 & 1,00 & 3,41 & $* * *$ \\
\hline Kesejahteraar & $<--$ & Tata Kelola & 0,65 & 0,92 & 3,38 & $* * *$ \\
\hline Kesejahteraar & $<--$ & Promosi & 0,76 & 1,00 & 3,51 & $* * *$ \\
\hline Kesejahteraar & $<-$ & Infrastruktur & 0,80 & 0,22 & 6,43 & $* * *$ \\
\hline
\end{tabular}

Hasil Uji Hipotesis Pengembangan Investasi Wilayah Perbatasan dengan signfikansi apabila nilai $\mathrm{CR}>1,96$ dan nilai $\mathrm{P}<0,05$. dapat disimpulkan bahwa variabel berpengaruh signifikan dengan nilai kritisnya yang identik dengan nilat $t_{\text {hitung, }}$ yakni 1,65 pada tingkat signifikansi $5 \%$ antara lain :

$\mathrm{H}_{1}$ Pengembangan investasi wilayah perbatasan melalui tata kelola instansi penanaman modal dibuktikan nilai $p<0,05$ yaitu $0,000<0,05$ dan nilai C.R pada tingkat signifikansi $p>1,96$ yaitu 3,38>1,96, disimpulkan pengembangan investasi melalui tata kelola instansi penanaman modal berpengaruh signifikan terhadap kesejahteraan masyarakat pesisir pada wilayah perbatasan sebesar 0,65 atau $67 \%$.

$\mathrm{H}_{2}$ Pengembangan investasi melalui promosi dibuktikan nilai $p<0,05$ yaitu $0,000<0,05$ dan nilai C.R pada tingkat signifikansi $p>1,96$ yaitu 3,41>1,96, disimpulkan Promosi untuk mencari investor berpengaruh signifikan terhadap Kesejahteraan masyarakat pesisir pada wilayah perbatasan sebesar 0,76 atau $76 \%$.

$\mathrm{H}_{3}$ Pengembangan investasi melalui pengadaan infrastruktur atau sarana prasarana dibuktikan nilai $p<0,05$ yaitu $0,000<0,05$ dan nilai C.R pada tingkat signifikansi $p>1,96$ yaitu $6,43>$ 1,96 , disimpulkan pengadaan infrastruktur atau sarana prasarana berpengaruh signifikan terhadap Kesejahteraan masyarakat pesisir pada wilayah perbatasan sebesar 0,80 atau $80 \%$.

Selain hipotesis yang diteliti dalam penelitian ini, terdapat pengaruh lainnya ditunjukkan dari hasil output SEM dari pengembangan investasi wilayah perbatasan terhadap pembangunan wilayah pesisir adalah: a) Pengembangan investasi wilayah perbatasan melalui tata kelola instansi penanaman modal berpengaruh signifikan terhadap pembangunan sebesar 0,41 atau $41 \%$. b) Pengembangan investasi wilayah perbatasan melalui promosi berpengaruh signifikan terhadap pembangunan sebesar 0,96 atau $96 \%$. c) Pengembangan investasi wilayah perbatasan melalui pengadaan infrastruktur atau sarana prasarana berpengaruh signifikan terhadap pembangunan sebesar 0,30 atau $30 \%$ dan d) Pengembangan investasi wilayah perbatasan melalui pembangunan berpengaruh signifikan terhadap 
Kesejahteraan masyarakat pesisir, Nilai pengaruhnya sebesar $73 \%$

Path DiagramModel Pengembangan Investasi Industri Maritim

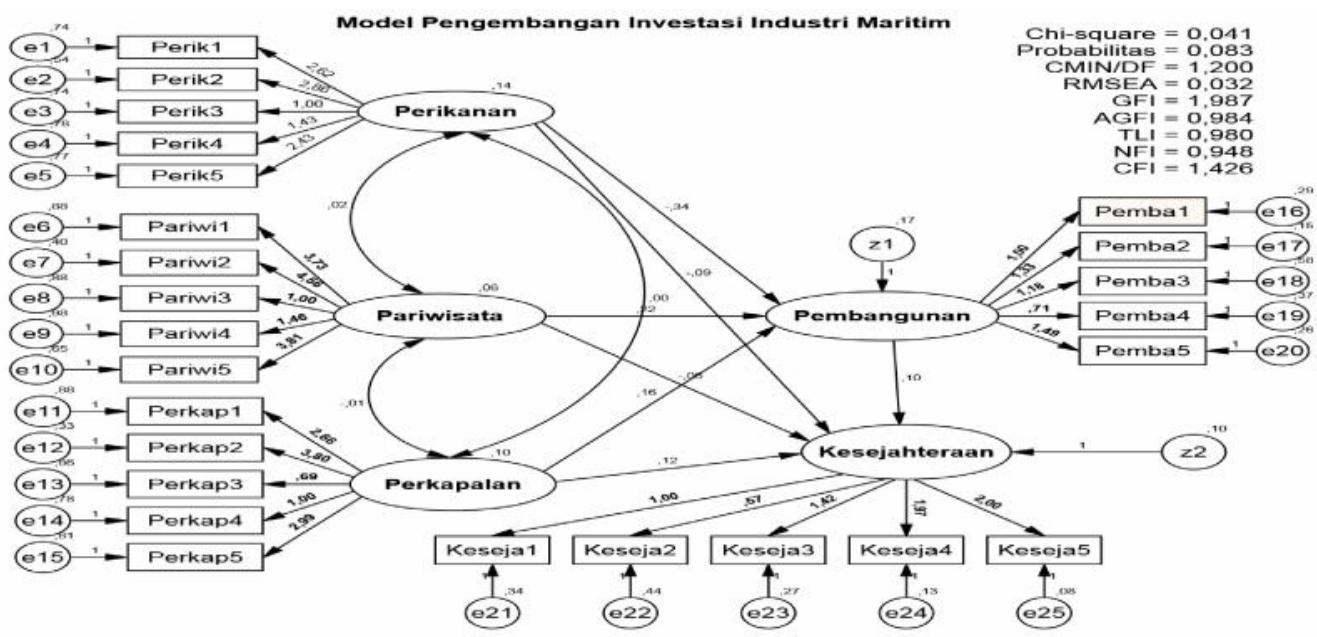

Gambar 2. Path Diagram Model Pengembangan Investasi Industri Maritim

\section{Pengembangan Investasi Industri Maritim}

Evaluasi model dilakukan untuk menguji kelayakan model melalui kriteria penilaian Goodness of Fit (GOF) sehingga diketahui apakah model tersebut telah fit atau belum. Berikut adalah rangkuman hasil pengujian output path diagram pengembangan investasi Industri Maritim uji goodness of fit dengan df $=268$ antara lain: nilai Chi-square 0,041 , nilai probability adalah 0,083 , CMIN/DF=1,200 $\leq 2,0$,
RMSEA $=0,032 \leq 0,08$ nilai uji goodness of fitmenunjukkan bahwa nilai memenuhi syarat goodness of fit, hal ini berarti model yang dihipotesiskan telah cocok dengan data observasi. Kecocokan model juga didukung dengan nilai $\mathrm{GFI}=$ $1,987 \geq 0,90$, $\mathrm{AGFI}=0,984 \geq 0,90$, $\mathrm{TLI}=0,980 \geq 0,90, \mathrm{NFI}=0,948 \geq 0,90$, $\mathrm{CFI}=1,426 \geq 0,95$ berada di atas nilai 0,9 dan nilai RMSEA berada antara interval 0,03 sampai 0,08 sehingga model dikatakan cocok terhadap data observasi.

Tabel 2. Hasil Estimasi Parameter dan Standard Error Investasi Industri Maritim

\begin{tabular}{|c|c|c|c|c|c|c|}
\hline \multicolumn{3}{|c|}{ Parameter } & Estimate & S.E. & C.R. & $\mathrm{P}$ \\
\hline Pembangunan & $<-$ & Perikanan & 0,740 & 0,105 & 7,049 & *** \\
\hline Pembangunan & $<-$ & Perkapalan & 0,539 & 0,119 & 4,532 & 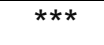 \\
\hline Pembangunan & $<-$ & Pariwisata & 0,741 & 0,116 & 6,373 & $\overline{\star \star N * \star}^{*}$ \\
\hline Kesejahteraan & $<-$ & Pembangunan & 0,435 & 0,053 & 8,138 & *** \\
\hline Kesejahteraan & $<-$ & Perkapalan & 0,481 & 0,026 & 3,131 & 0,002 \\
\hline Kesejahteraan & $<-$ & Perikanan & 0,539 & 0,119 & 4,532 & $\star \star \star ~$ \\
\hline Kesejahteraan & $<--$ & Pariwisata & 0,981 & 0,125 & 7,829 & $\star \star \star$ \\
\hline
\end{tabular}

Hasil uji hipotesis pengembangan investasi industri maritim adalah sebagai berikut :

$\mathrm{H}_{4}$ Pengembangan investasi indus- 
tri maritim melalui bidang perikanan berpengaruh signifikan terhadap kesejahteraan masyarakat pesisir sebesar 0,539 atau $53,9 \%$.

$\mathrm{H}_{5}$ Pengembangan investasi industri maritim melalui bidang pariwisata bahariberpengaruh signifikan terhadap kesejahtera- an masyarakat pesisir sebesar 0,981 atau $98,1 \%$.

$\mathrm{H}_{6}$ Pengembangan investasi industri maritim melalui bidang perkapalanberpengaruh signifikan terhadap kesejahteraan masyarakat pesisir sebesar 0,481 atau $48,1 \%$.

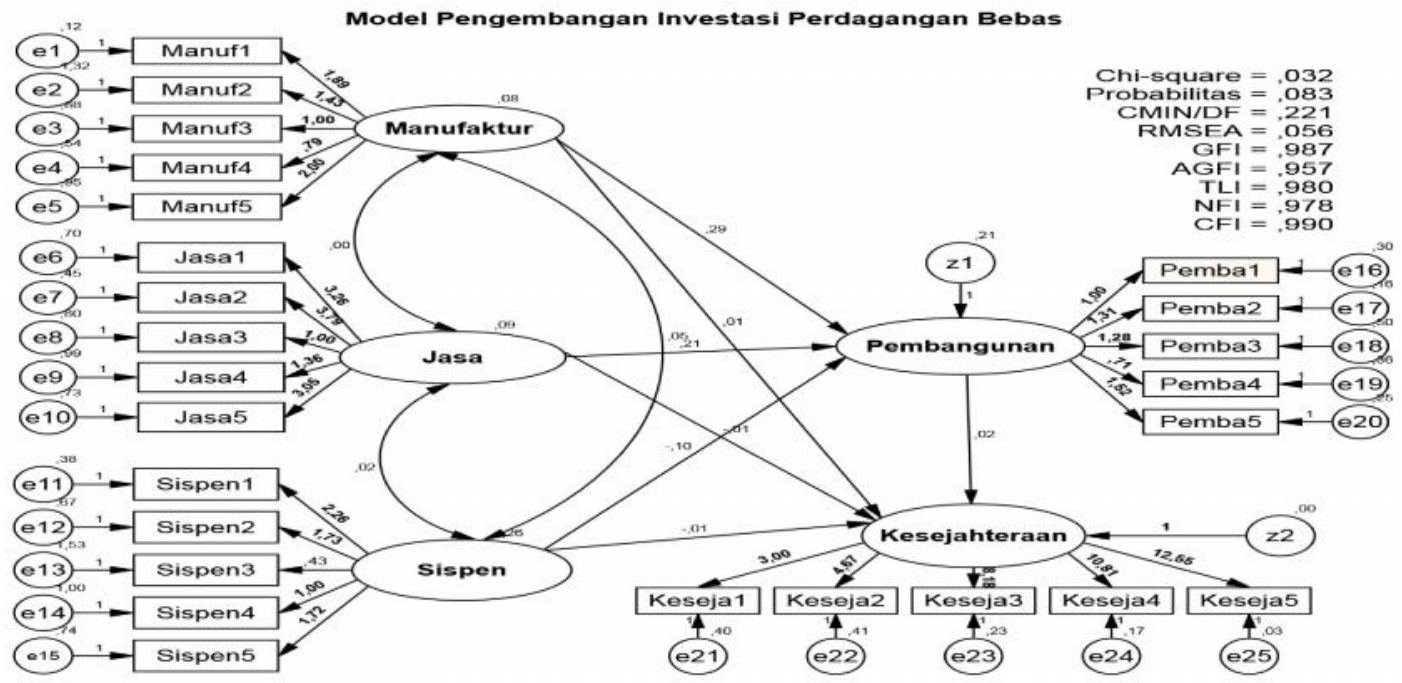

Gambar 3.Path Diagram Model Pengembangan Investasi Kawasan Perdagangan Bebas

\section{Pengembangan Investasi Ka- wasan Perdagangan Bebas}

Evaluasi model dilakukan untuk menguji kelayakan model melalui kriteria penilaian Goodness of Fit (GOF), hasil pengujian output path diagram pengembangan investasi wilayah perbatasan untuk goodness of fit dengan df $=268$ antara lain: nilai Chi-square 0032 , nilai probability adalah 0,083, $\mathrm{CMIN} / \mathrm{DF}=0,221 \leq 2,0, \quad \mathrm{RMSEA}=$ $0,056 \leq 0,08$ nilai uji goodness of fit menunjukkan bahwa nilai memenuhi syarat goodness of fit, hal ini berarti model yang dihipotesiskan telah cocok dengan data observasi. Kecocokan model juga didukung dengan nilai $\mathrm{GFI}=0,987 \geq 0,90$, $\mathrm{AGFI}=\quad 0,957 \geq \quad 0,90, \quad \mathrm{TLI}=$ $0,980 \geq 0,90, \mathrm{NFI}=0,978 \geq 0,90, \mathrm{CFI}=$ $0,990 \geq 0,95$ semua pengujian memenihi syarat uji GOF, sehingga model dikatakan cocok terhadap data observasi. 
Tabel 3. Hasil Estimasi Parameter dan Standard Error Kawasan Perdagagan Bebas

\begin{tabular}{l|c|l|c|c|c|c}
\multicolumn{2}{c|}{ Variabel } & Estimate & S.E. & C.R. & P \\
\hline Pembangunan & $<-$ & Manufaktur &, 287 & 0,238 & 1,207 & 0,228 \\
\hline Pembangunan & $<--$ & Sispen &, 992 &, 124 & 7,968 & ${ }^{* * *}$ \\
\hline Pembangunan & $<--$ & Jasa &, 210 & 0,174 & 1,206 & 0,220 \\
\hline Kesejahteraan & $<-$ & Pembangunan &, 731 &, 172 & 8,917 & ${ }^{* * *}$ \\
\hline Kesejahteraan & $<--$ & Jasa &, 652 &, 116 & 8,654 & ${ }^{* \star *}$ \\
\hline Kesejahteraan & $<-$ & Manufaktur &, 724 &, 167 & 7,945 & ${ }^{* * *}$ \\
\hline Kesejahteraan & $<--$ & Sispen &, 954 &, 194 & 4,908 & \multirow{2}{***}{}
\end{tabular}

Sumber Output Amos V.22, (2016)

Hasil uji Hipotesis Pengembangan Investasi Kawasan Perdagangan Bebas berdasarkan hasil output SEM masing-masing variabel dalam pengujian.

$\mathrm{H}_{7} \quad$ Pengembangan investasi kawasan perdagangan bebas melalui pengembangan industri manufaktur berpengaruh signifikan terhadap kesejahteraan masyarakat pesisir sebesar 0,724 atau $72,4 \%$

$\mathrm{H}_{8} \quad$ Pengembangan investasi kawasan perdagangan bebas melalui pengembangan jasa berpengaruh signifikan terhadap kesejahteraan masyarakat pesisir sebesar 0,652 atau $65,2 \%$

$\mathrm{H}_{9}$ Pengembangan investasi kawasan perdagangan bebas melalui pengembangan sistem pendukung berpengaruh signifikan terhadap kesejahteraan masyarakat pesisir sebesar 0,954 atau $95,4 \%$

\section{KESIMPULAN DAN SARAN}

Berdasarkan hasil pengujian GOF diketahui bahwa: (1) Model pengembangan investasi wilayah perbatasan pada Kota Batam, Kabupaten Bintan dan Kabupaten Karimun di Provinsi Kepulauan Riau dengan path diagram model, model ini telah teruji dan memenuhicut off value uji kriteria Goodness of Fit (GOF), sehingga model layak dan cocok terhadap observasi; (2) Model pengembangan investasi industri maritim pada Kota Batam, Kabupaten Bintan dan Kabupaten Karimun di Provinsi Kepulauan Riau dengan path diagram model, model ini telah teruji dan memenuhi cut off value uji kriteria Goodness of Fit (GOF), sehingga model layak dan cocok terhadap observasi, dan (3) Model pengembangan investasi kawasan perdagangan bebaspada Kota Batam, Kabupaten Bintan dan Kabupaten Karimun di Provinsi Kepulauan Riau dengan path diagram model, model ini telah teruji dan memenuhi cut off value uji kriteria Goodness of Fit (GOF), sehingga model layak dan cocok terhadap observasi.

Selanjutnya, berdasarkan pengujian, maka:

$\mathrm{H}_{1}$ : Pengembangan investasi wilayah perbatasan melalui tata kelola instansi berpengaruh signifikan terhadap Kesejahteraan masyarakat pesisir pada wilayah perbatasan sebesar 0,65 atau $67 \%$. 
$\mathrm{H}_{2}$ : Pengembangan investasi melalui promosi berpengaruh signifikan terhadap Kesejahteraan masyarakat pesisir pada wilayah perbatasan sebesar $76 \%$

$\mathrm{H}_{3}$ : Pengembangan investasi melalui pengadaan infrastruktur atau sarana prasarana berpengaruh signifikan terhadap Kesejahteraan masyarakat pesisir pada wilayah perbatasan sebesar $80 \%$.

$\mathrm{H}_{4}$ : Pengembangan investasi industri maritim melalui bidang perikanan berpengaruh signifikan terhadap kesejahteraan masyarakat pesisirsebesar 53,9\%.

$\mathrm{H}_{5}$ : Pengembangan investasi industri maritim melalui bidang pariwisata bahari berpengaruh signifikan terhadap kesejahteraan masyarakat pesisirsebesar $98,1 \%$.

$\mathrm{H}_{6}$ : Pengembangan investasi industri maritim melalui bidang perkapalan berpengaruh signifikan terhadap kesejahteraan masyarakatpesisir 48,1\%.

$\mathrm{H}_{7}$ : Pengembangan investasi kawasan perdagangan bebas melalui pengembangan industri manufaktur berpengaruhsignifikan terhadap kesejahteraan masyarakat pesisir $72,4 \%$

$\mathrm{H}_{8}$ : Pengembangan investasi kawasan perdagangan bebas melalui pengembangan jasa berpengaruh signifikan terhadap kesejahteraan masyaraka tpesisir sebesar $65,2 \%$.

$\mathrm{H}_{9}$ : Pengembangan investasi kawasan perdagangan bebas melalui pengembangan sistem pendukung berpengaruh signifikan terhadap kesejahteraan masyarakat pesisir sebesar $95,4 \%$

Strategi Kebijakan

1. Pengembangan investasi wilayah perbatasan dilakukan melalui 3 aspek yaitu tata kelola lembaga/instansi penanaman modal, promosi potensi wilayah dan pengadaan/perbaikan infrastruktur atau sarana prasaranautama.

2. Pengembangan investasi industri maritim dapat dilakukan berdasarkan tiga konsep utama yaitu: pengelolaan industri perikanan, peningkatan dan pengelolaan wisata bahari dan perbaikan industri perkapalan.

3. Pengembangan investasi kawasan perdagangan melalui tiga konsep aspek antara lain: peningkatan jumlah industri manufaktur, meningkatkan usaha bidang jasa dan menyediakan sistem pendukung untuk kawasan perdagangan bebas.

\section{DAFTAR PUSTAKA}

BKPM. (2011). Kajian Investasi Wilayah Perbatasan. Jakarta: Badan Koordinasi Penanaman Modal dan Komite Pelaksanaan Otonomi Daerah.

Dahuri, R. (2010). Melirik Ekonomi Kelautan. Bogor: Institut Pertanian Bogor.

Dimyati, H. (2009). Membangun Negara Maritim Dalam Perspektif Ekonomi, Sosial, 
Budaya, Politik, Dan

Pertahanan. Jakarta: Indonesia Maritim Institute (IMI).

Effendi, d. (2012). Opsi Pengembangan Kawasan Perbatasan Kabupaten Belu (RI) dan Timor Leste (Melalui Pendekatan Empirik Dan Perbandingan Model Teoritis Dari Beberapa Kasus Negara). Seminar Nasional Sains dan Teknik 2012 (SAINSTEK 2012). Kupang.

Kusumastanto, T. (2014). Arah Strategi Pembangunan Indonesia Sebagai Negara Maritim. Bogor: Pasca Sarjana Ekonomi Sumberdaya Kelautan Tropika, Departemen Ekonomi Sumberdaya dan Lingkungan, Fakultas Ekonomi dan Manajemen, Institut Pertanian Bogor.

Manik, T. (2014). Analisis Pengaruh Industri Maritim Melalui Transportasi Perhubu-ngan Laut, Pariwisata Bahari,
Perikanan Tangkap Terhadap Pendapatan Asli Daerah dan Pertumbuhan Aset (Studi di Propinsi Kepuluan Riau Melalui Pendekatan Analisis Jalur). Jakarta: Kementerian Pendidikan dan Kebudayaan.

Reinhold, Y. d. (2008). Kajian Faktor Pendorong Pengembangan Kawasan Perba-tasan Jayapura, Indonesia Vanimo, Png. Jurnal Pembangunan Wilayah dan Kota, Volume (4). April 2008.

Sihaloho, T. d. (2009). Kajian Dampak Ekonomi Pembentukan Kawasan Ekonomi Khusus. Jakarta: Puslitbang Iklim Usaha Perdagangan, Kementerian Perdagangan.

Suroso. (2015). Poros Maritim dan Perkembangan Perekonomian Indonesia, Kementerian Keuangan. Jakarta: Badan Pendidikan Pelatihan dan Pelatihan Keuangan. 